\title{
VRAELYS AAN EN ANTWOORDE VAN 'N PREDIKANT IN VERBAND MET DIE VERSKILLENDE HOMILETIESE FASETTE VAN DIE PREDIKING
}

1. Doel:

Wat beoog $u$ met $u$ prediking? Onbeantwoord.

\section{Tekskeuse}

1.1. Hoe kom u tot die keuse van 'n teks?

1.1.1. Deur gereelde stelselmatige Bybellees? Nee.

1.1.2. Deur aandagtige lees van koerante? Nee.

1.1.3. Deur die soek van 'n teks in vermoedelik toepaslike gedeeltes n.a.v. die sg. kerklike jaar? Ja.

1.1.4. Deur die lees van homiletiese werke? Nee.

1.1.5. Deur gesprekke met lidmate en versoeke van hulle kant i.v.m. Skrifdele of probleme? Nee.

1.1.6. Deur beplande Bybellees saam met verklarende aantekeninge, parafrases, kommentare, ens.? Nee.

1.1.7. Laat $u$ u ook lei deur die pastorale behoeftes van die gemeente? Ja.

1.2. Enige ander wyse? Spesifiseer asseblief. Vanuit eie ervaringslewe van die week. Dit is inderdaad subjektief, maar as mensmet-ervaring kan ek aanneem dat ander mense ook dieselfde ervarings sal hê. Hoofsaaklik dus vanuit subjektiewe probleemsituasie gekom tot die Woord.

\section{Die inleiding en slot van die preek}

2.1. Wat beoog u met die inleiding en slot van u preek? Probleemstelling. Slot: Antwoord op probleemstelling en probeer antwoord van gemeente op die preek, aan God, vertolk.

2.2. Watter vereistes stel u vir die inleiding en slot? Baie pakkend. Emosioneel geformuleer om dadelik spankrag van gemeente te kry. Helderheid.

2.3. Watter gevare meen u moet vermy word by die inleiding en slot? Langdradigheid. Historiese aanpak.

2.4. Watter lengte ag u geskik vir die inleiding? Twee minute.

2.5. Hoe belangrik ag $u$ die inleiding en waarom maak u die bewering? Inleiding is invalspoort van preek en moet verwagting en aandag stimuleer.

2.6. Watter soort inleidings het $u$ al oor die radio of elders gehoor waarteen u miskien wil waarsku? Waar tema aangekondig word. Jy skiet jou koeëls weg voor jy begin.

2.7. Watter waarde ken $u$ toe aan die slot in die geheel van die preek en hoe probeer u dit verwerklik? Dis die laaste inprent van die preek. Weer eens emosioneel aanpak want emosionele aanpak gryp meer in as intellektuele.

\section{Tema en verdeling}

3.1.1. Wat is 'n tema t.o.v. 'n preek? Die greep of snit of kerngedagte 
wat in die hele preek gedra word.

3.1.2. Wat is 'n tematiese preek? In my ,begrippe-gereedskap" ' $n$ preek wat een enkele gedagte of tema oordra.

3.1.3. Definieer asseblief die begrippe: tema; hoofgedagte; sentrale gedagte; eenheid van die preek. Alles dieselfde. Sien 3.1.1.

3.2. Hoe kom u tot die verdeling van u preek? Deur die tema logies te ontwikkel. Dis een metode of deur die reaksie van die hoorders te antisipeer en daarvolgens stof te verdeel.

3.3. Gee u voorkeur aan:

3.3.1. Enkelversprediking, perikoop, homilie, kaleidoskopiese prediking, „verrassende" prediking waarin die tema eers teen die einde uitkristalliseer? Enkelversprediking.

3.3.2. Watter opvatting huldig $u$ oor die probleemstelling in bg. (3.3.1.) vervat? Een enkele gedagte is die effektiefste. Daarom 1 vers.

3.3.3. Hoe gaan $u$ te werk wanneer in die teks, perikoop of homilie meer as een hoofgedagte vervat is? Noem verskillende en sê ek gaan net op een van die baie hoofgedagtes konsentreer.

3.4. Hoe bewoord $u$ die hoofgedagte:

3.4.1. Deur die gangbare idioom (met voorkeur aan die moderne taalgebruik) in ag te neem? $\mathrm{Ja}$.

3.4.2. Deur soveel moontlik tekswoorde feitlik as slagspreuk te gebruik? Nee.

3.4.3. Deur bepeinsing van die eksegese om so te kom tot formulering van die tema uit u begrip van die inhoud van die teks? Ja.

3.4.4. Deur 'n tema aan 'n kommentaar of homiletiese werk te ontleen? Nee.

3.4.5. Wat is $\mathrm{u}$ eie metode? Vanuit probleemstelling tema te formuleer.

3.5. Oor die verdeling en sg. ,punte" in die preek bestaan daar uiteenlopende menings.

3.5.1. Wat is $\mathrm{u}$ mening daaroor? Vervelend en psigologies onverantwoord. Neem verrassing weg.

3.5.2. Wat dink u van die eise van logika vir die bou van 'n preek? Essensieel.

3.5.3. Indien $u$ wel met ,hoeke van benadering” of „punte" in $u$ preek wil reken, hoedanig moet dit wees en aangewend word? Vanself uitkristalliseer; kan as saamvatting punte aanwend en eksplisiet stel.

3.5.4. Watter ander kenmerke het die bou van 'n preek? Inleiding eksegetiese verkenning van tekstema ,gevind" as neerslag van eksegese-toepassingsaamvatting - slot.

3.6. Gee asseblief u gedagtes i.v.m. herhaling in die prediking?

3.6.1. Die rede vir herhaling. Ter wille van tuisbring van 'n gedagte.

3.6.2. Die plek van doelbewuste herhaling. Ja, maar altyd anders gestel. Selfde gedagte progressief formuleer.

3.6.3. Die gevare van onbewuste herhaling. Baie groot.

3.6.4. Hoe kan onnodige herhaling vermy word? Deur nie vry te preek nie. 


\section{Explicatio}

4.1. Wat hou die explicatio vir $u$ in?

4.1.1. 'n Onderwerp wat $\mathrm{u}$ uit 'n teks probeer haal? Ja.

4.1.2. 'n Teks wat $u$ in sy logiese sinsverband probeer ,oopmaak"? $\mathrm{Ja}$.

4.1.3. 'n Bepaalde Skrifgedeelte (teks of perikoop) wat u wil ,oopmaak"? Ja.

4.1.4. 'n Bepaalde boodskap wat $u$ uit die teks of met die teks probeer bring? Nee.

4.1.5. Hou dit vir u iets anders as bg. in? Spesifiseer asseblief. Nee.

4.2. Wat is $u$ evaluering van eksegese, openbaringsgeskiedenis, kanoniek en dogmatiek t.o.v. die explicatio? Almal nodig. Dis studeerkamerwerk en moet skaars op die preekstoel kom.

4.3. Wat is $u$ mening i.v.m. die leeraspek (didaskein) in die prediking? Hoe gaan $u$ te werk om dit in die prediking te verdiskonteer? Essensieel, maar nooit te sterk „lewend" aangebied nie.

4.4. Stel u 'n prioriteit tussen explicatio en applicatio in u prediking? Motiveer asseblief. Albei ewe sterk - 50/50. Die Woord (explicatio). Nou (Applicatio).

4.5.1. Watter kommentare gebruik u i.v.m. die explicatio? (Noem die werke op u rak met die oog op statistiek): Kampen, Kok. Commentaar op het Oude Testament. Red. Gispen, M. H. Ridderbos. Nuwe Testament Bottenburg-serie.

4.5.2. Watter van bg. kommentare wil u sterk aanbeveel? Sien bo.

4.6. In die lig van bg. (4.1.-4.5.) hoe moet die verklaring na $u$ mening plaasvind? Gelei deur vraag: Wat wil God hier sê.

4.6.1. Watter kenmerke het 'n ,geslaagde" preekverklaring? Helderheid.

4.6.2. Waaraan kan 'n mens minder geslaagde verklaring van 'n preek onderken? 'n Geskarrel en langdradige detail wat nie relevant is nie. Of die „storie” net oorvertel - en dit dan eksegese te noem.

\section{Die Applicatio}

5.1. Watter rol speel die toepassing in u hele proses van preek-maak? Dit word nie 'n aanhangsel nie, maar die konkrete "uitloop" van die preek.

5.1.1. Soek $u$ stof omdat $u$ 'n sekere lig op 'n bepaalde probleem wil werp - ongeveer soos 'n dokter wat na diagnose medisyne vir die kwaal probeer vind? Ja.

5.1.2. Verklaar u die teks (perikoop) en laat dan die toepassing oor aan gedagtes wat in die proses van verklaring gebore word? Nee.

5.1.3. Watter ander eie metode wend $u$ aan? Sien 1.

5.2.1. In hoeverre moet ' $n$ prediker sy toepassing aanpas by die smaak van die gemeente? (Bv. sal $u$ in 'n preek oor Sondag 42 vr. III H.K. op die platteland lone van plaasarbeiders aanraak of dit liefs t.w.v. stigting vermy?). Nie smaak nie. Aktueel toepas - die leefwêreld van die spesifieke gemeente betrek.

5.2.2. Hoe sien u die verhouding en probleem tussen toepassing wat stig en ontstig i.v.m. die manier waarop die prediker dit bring? 
Toepassing wat ontstig is as die dominee sy troetelgedagtes indra en die toepassing nie direk voortvloei uit die verklaring nie.

5.3. Hoe sien $u$ die gerigtheid van die prediking op die gemeente t.o.v. eenheid en differensiasie (bv. ouderdom, beroep, verskil in begripsvermoë, psigologiese gevarieerdheid, ens.)? Tog differensiasie in gemeente in ag neem.

5.4. Wat beskou u as die ,eietydse" van die mens en wêreld van vandag? In een woord: relatiwisme.

5.4.1. Hoe probeer $u$ op hoogte kom en bly met die hedendaagse lewensgevoel, kultuurpatroon en die besondere pastorale probleme van ons tyd, ens.? Leeswerk. Ook moderne romans. Sosiologie, politiek, kultuuranalises ens.

5.4.2. Hoe gebruik u dit met die oog op u toepassing? Ken lewensgevoel van moderne mens "maak" die toepassing.

5.5. Wat is $u$ beskouing oor die moderne gedagtes t.o.v. aktueler prediking bv. die dialogiese metode (bv. dat die prediker in sy preek ook vrae stel wat leef in die harte van die hoorders; dat hy in lyn met die moderne lewensgevoel meer soekend preek en nie „,aanseggend" nie); op die jeug gerigte prediking; diskussie na die diens oor die preek; Bybelstudie i.p.v. prediking; enige ander gangbare opvatting wat $u$ teëgekom het en in hoeverre $\mathrm{u}$ dit positief of negatief waardeer? Al die dinge genoem in $n r$. 5.5. - van harte ja.

5.6.1. Die prediker staan in diens van die gemeente en ontvang sy roeping van God. Hoe en in hoeverre identifiseer hy hom in die prediking met sy roeping deur God, en hoe en in hoeverre identifiseer hy hom in die prediking met die gemeente? Albei. Vraag is nie korrek. Hy bly mens teenoor God en word nooit ,verteenwoordiger" van God by die mens nie.

5.6.2. Hoe vermy die prediker die gevaar dat hy die hoorders aan. stoot gee deur 'n houding van „afstand", „, heilig-wees", afsydigheid, ens.? Solidariteit steeds te belewe.

5.6.3. In hoeverre het die prediker te doen met die probleem dat hy slegs in 'n beperkte veld kan toepas (bv. Bybellees, gebed, bydraes, kerkbesoek, ens.) - en sodoende nie die leefwêreld van die lidmate bereik nie? Hoe kan hy dit vermy? Hele wêreld is sy toepassingsveld.

5.6.4. Hoe kan die indikatief van die genade, die imperatief van die dankbaarheid en die bevindelike in die toepassing tot sy reg kom? Vgl. alles wat tot sover genoem is.

\section{Die Homiletiek as vak}

6.1. Is daar ' $n$ bepaalde homiletiek wat uit $u$ opleiding stam of wat u as gangbaar ,gereformeerd" beskou waarmee u

6.1.1. Definitief gebreek het? Ja. Die tipies Gereformeerde leerprediking en Calvyn se tipe prediking.

6.1.2. Waarby $u$ hou om nie aanstoot te gee nie, hoewel dit $u$ nie bevredig nie? N.v.t.

6.2. Watter "leemtes" merk $u$ by uself en ander gereformeerde predikante op wat as 'n kenmerkende opleidingsleemte bestem- 
pel kan word? Te min sensitief vir die mense vir wie gepreek moet word. Geen eksistensiële belewing. Gebrekkige kennis van ,adres" van die prediking.

6.3. Is daar leemtes wat $\mathrm{u}$ agterna in $\mathrm{u}$ eie homiletiekvorming ontdek het? Ja. Vgl. 6.2 .

\section{Formeel}

7.1. Wat is $u$ mening oor die taalgebruik van predikante in terme van die volgende leidinggewende woorde, predikante-taal; teologiese vaktaal; kanseltaal; tale Kanaäns; cliches; gebruik van die abstrakte selfstandige naamwoord of konkrete werkwoord ens.? Vermy alles genoem in vraag. Eenvoud en werkwoord is noodsaaklik.

7.2.1. Watter rol speel taal en tipe taalgebruik in die kommunikasie? Deurslaggewend.

7.2.2. Hoedanig bevorder $u$ kommunikasie in $u$ prediking deur te konsentreer op $\mathrm{u}$ taalgebruik en -versorging? Besonder baie. Skrywe preke tot vier maal oor ter wille van keurige taal.

7.3. Watter kenmerke, meen $u$, moet die taal vir die prediking hê en watter gevare moet vermy word? Vgl. 7.1.

7.4. Watter praktiese wenke kan vir die bevordering van preektaal in ag geneem word? (Bv. lees van digbundels, voorbeelde van Okke Jager, die gevaar van die redeneertrant met woorde en sinne soos "want" en "omdat" ens.? Digbundels belangrik. En goeie Afrikaanse boek.

7.5. Wat is $u$ ervaring (voordele en nadele) t.o.v. preke sonder skets; preke met 'n korter of langer skets; preke wat volledig uitgeskryf is? Volledig uitskrywe is by verre die voordeligste.

7.6. Watter probleme moet $u$ telkens weer in $u$ eie hart en lewe oorkom om te kan preek? Behalwe die persoonlike stryd met boesemsondes, die angs dat $j y$ in die preek nie gaan slaag nie.

7.7. Watter metodes stel $\mathrm{u}$ in werking om $\mathrm{u}$ prediking te evalueer (bv. terugspeel op bandopnemer; gesprek met kerkraadslede of gemeentelede, ens.)? Wat genoem word in 7.7. is noodsaaklik. Daar moet stelselmatige evaluasie wees.

7.8.1. Maak $u$ in die reël elke week twee nuwe preke? Ja.

7.8.2. Wat is u mening i.v.m. die herhaling van 'n „ou" preek? Goed, so 3 maal. Dan is sy pit uit.

7.8.3. Hoeveel tyd bestee $u$ weekliks aan die voorbereiding van $u$ preke? Drie volle voormiddae.

Voetnoot: Onveranderd geplaas. 